Jurnal Riset Biologi dan Aplikasinya, Volume 3, Issue 2, September 2021

Jurnal Riset Biologi dan Aplikasinya
https://journal.unesa.ac.id/index.php/risetbiologi

\title{
The Population of Sanderling (Calidris alba) in 2020 Migration on the South Coast of Puger, Getem, Jember
}

\author{
Abdu Rohman ${ }^{1 *}$, Ragil Satriyo Gumilang ${ }^{2}$ \\ ${ }^{1}$ Biology Education, Faculty of Teacher Training and Education, University of Jember \\ ${ }^{2}$ Wetlands International Indonesia \\ Jln. Kalimantan No. 37, Kampus Tegalboto, Jember, Jawa Timur, 6812 1, Indonesia \\ *Corresponding Author: \\ e-mail: abdu.fkip@unej.ac.id
}

\section{Article History}

Received : 7 April 2021

Revised : 2 June 2021

Approved : 4 September 2021

Published : 30 September 2021

\section{Keywords}

population; Calidris alba; migration; shorebird

\begin{abstract}
Sanderling (Calidris alba) is a species of shorebird that migrates from the northern hemisphere to the southern hemisphere. Indonesia is a migration route for East Asia-Australasia. The southern coastal area of the Jember Regency, one of the wetlands, especially in East Java, has become an air route and a stopover for shorebirds every year. The research objective was to determine the population of Sanderling (Calidris alba) on the southern coast of Puger and Getem, Jember Regency. Method of data collection was encounter rates. Bird watching was carried out in the morning at 06.00-08.00 am and in the afternoon at 03.30-05.30 pm. Data recording included species, number of birds, and other supporting data. Data was analyzed using the density index for individual bird species. The results of the study showed that there were a total of 445 individuals. The highest population was found in the river mouths, while the ponds were the minor location. Analysis of individual density data showed that the river estuary was the location with the highest number of the four other survey locations.
\end{abstract}

How to cite: Rohman, A \& Gumilang, R.S. (2021). The population of Sanderling (Calidris alba) in 2020 Migration on the South Coast of Puger, Getem, Jember. Jurnal Riset Biologi dan Aplikasinya, 3(2): 63-67. DOI: 10.26740/jrba.v3n2.p63-67

\section{INTRODUCTION}

Sanderlings (Calidris alba) is a species of shorebird that migrates from the northern hemisphere to the southern hemisphere (Robert et al., 2005; Yong et al., 2018). Indonesia is a migration route for East Asia-Australasia (Howes et al., 2003; Robert et al., 2005). Crossland et al. (2010) stated that Sanderling had been recorded at several locations on the south coast of Java. Research by Taufiqurrahman et al. (2010) noted that the southern coast of Trisik in Yogyakarta is a critical location for Sanderling's existence. Crossland et al. (2014) reported another location, namely Glagah Beach, a wetland on Java's southern coast. This site is an important national and international nonmigratory breeding site for Sanderling (Calidris alba). Another location on the south coast of Java, where Sanderlings are flying, is the southern coastal area of Jember Regency.

The southern coastal area of the Jember Regency is one of the wetlands, especially in East Java, and is an annual flight route and a stopover for shorebirds. There are several habitats, including mangrove forests, beaches, river estuaries, rice fields, and ponds. This makes the southern coast of Jember Regency frequently visited by migratory shorebirds (Symonds and Langslow, 1996; Sibuea, 1997; Purify et al., 2019). Every year, during the migration season, hundreds of waterbirds can be found stopping in this area, hence the south coast of Puger, Getem is an essential location for migratory shorebirds in Jember Regency.

Another phenomenon in the southern coastal area of Puger, Getem, Jember Regency is the number of various human activities in this area. For 
example, fishing, ecotourism, and fishing boat traffic activities (Klein et al., 1995; Rodgers Jr. \& Schwikert, 2002; Clark \& Koslow, 2008; Borgmann, 2011). Such conditions in the long term will directly impact the sustainability of migration using the southern coastal area of the Jember Regency as a stopover, especially in looking for food. Also, changes in transit habitat can severely limit migratory populations (Studds et al., 2017). Efforts are needed to conserve the migration of shorebirds that migrate in one part of the home range is less effective if unsolved threats reduce this species' population and habitat in other places (Kirby et al., 2008). Therefore, it is essential to maintain the transit habitat to sustain shorebirds' migration, especially Sanderling.

Based on this explanation and the survey results, there was population of Sanderling shorebirds (Calidris alba), especially in the southern coastal area of Puger, Getem. Therefore, this study aimed to analyze the population of Sanderling (Calidris alba) on the south coast of Puger and Getem, Jember Regency.

\section{MATERIALS AND METHODS}

The research location was on the south coast of Puger, Getem, Jember Regency, East Java Province. Location coordinates - 8.379 Latitude 113.406 Longitude. The four survey locations were river estuaries, mangrove forests, ponds, and along the southern coastline of Puger, Getem (Figure 1).

The research was conducted from February to April 2020. Using the tools in this study include Binocular Binoculars, Svbony SV408 Spotting Scope Monocular Binoculars, Tripod Somita ST3520, Nikon D5300, and 200mm Telelens Cameras and Garmin GPS. The data collection method uses encounter rates. Every bird found in the estuary area, mangrove forest, ponds, and along the southern coastline of Puger, Getem Jember was observed and counted. The observation was carried out in the morning (06.00-08.00 am) and evening at (03.30-05.30 pm). Field data recording included species, number of birds, habitat, and several other supporting factors. The identification was conducted based on morphological characters, namely size, color, and sound as well Furthermore, identifying shorebirds using the book by Hayman et al. (1991), Bhushan, B., et al. (1993), and Mackinnon et al. (2010).

Density data analysis of individual birds was calculated using the method with the formula (Alikodra, 1990):

$$
\begin{aligned}
& D=\frac{N}{A} \\
& \mathrm{D}=\text { density of the bird (indvidual / ha) } \\
& \mathrm{N}=\text { estimated population (individual). } \\
& \mathrm{A}=\text { Area represented }
\end{aligned}
$$

\section{RESULTS AND DISCUSSION}

Sanderling (Calidris alba) is a shorebird species that has a conservation status according to the IUCN Red List (International Union for Conservation of Nature) is Least Concern. This bird has the characteristics of relatively small size of about $20 \mathrm{~cm}$, gray with striking black shoulders. Looks whiter than other types of soy. At the same time, it was flying on a wing with a white cross. The middle tail is dark with white sides. Dark brown iris, black beak, and legs. Sounds' Clip clip chip when flying (Bhushan, et al., 1993, MacKinnon et al., 2010).

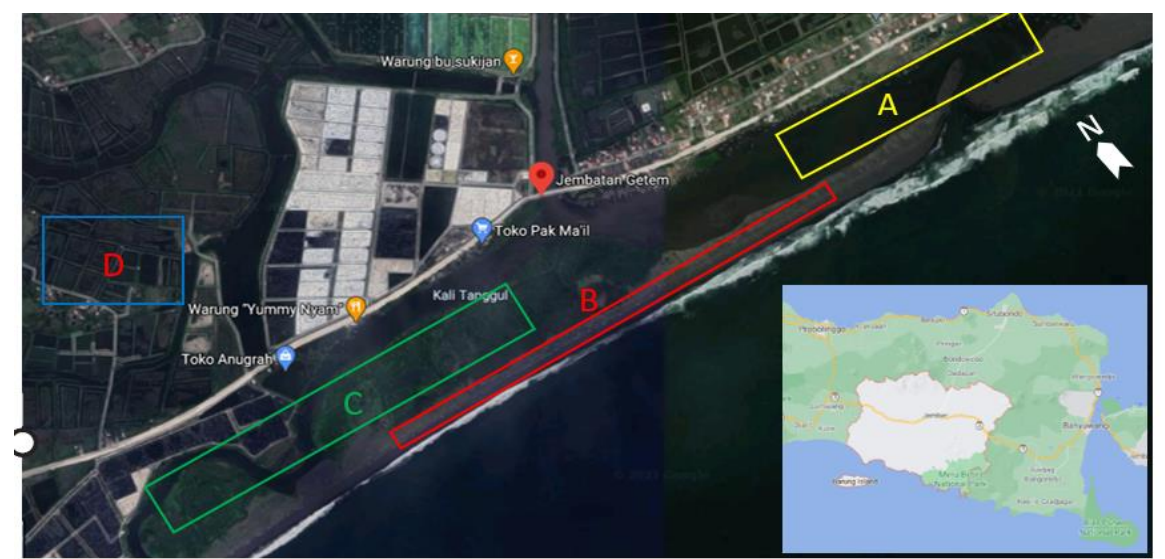

Figure 1. Location of the survey by Calidris alba on the South Coast of Puger, Getem, Jember. A. River Estuary; B. Coastal; C. Mangrove Forest; D. Pond. (Source: Google Map) 


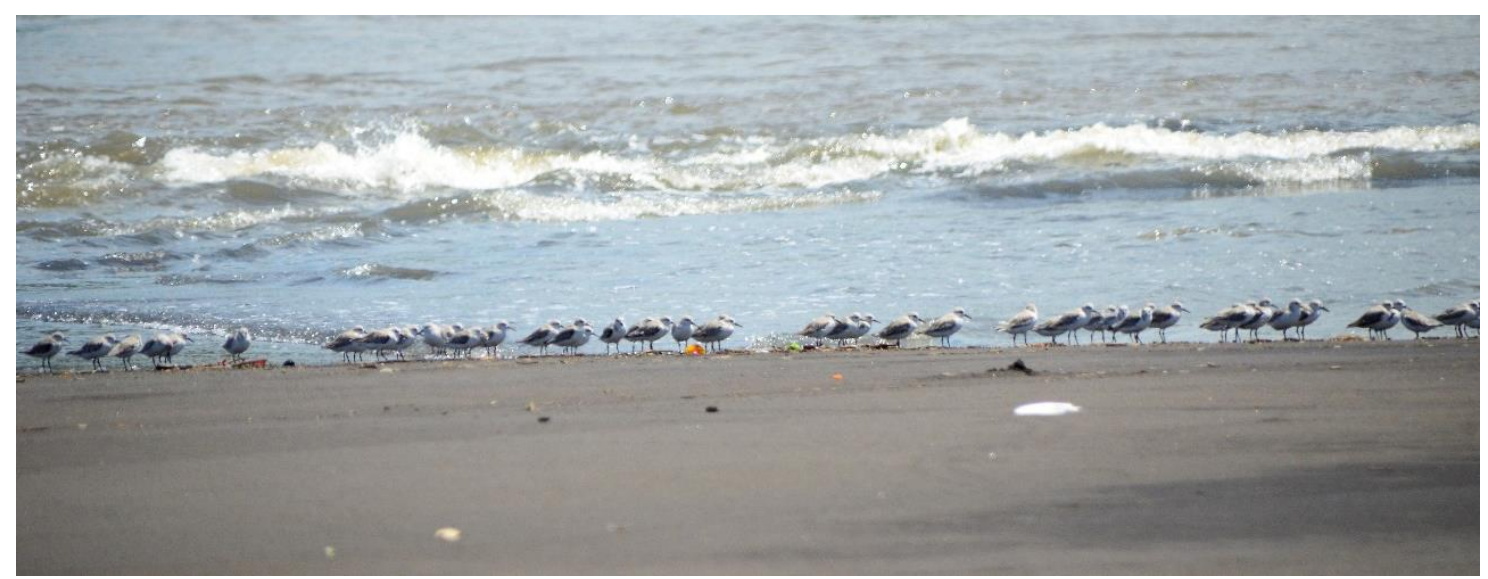

Figure 2. Population of Calidris alba on February 16, 2020

Table 1. The population of Calidris alba on the South Coast of Jember

\begin{tabular}{clcc}
\hline No & & Location & individuals \\
\hline 1 & Estuary & & 231 \\
2 & Coast & 184 \\
3 & Mangrove forest & 40 \\
4 & Pond & & 33 \\
\hline \multicolumn{2}{r}{} & \multicolumn{2}{c}{ Total } \\
\hline
\end{tabular}

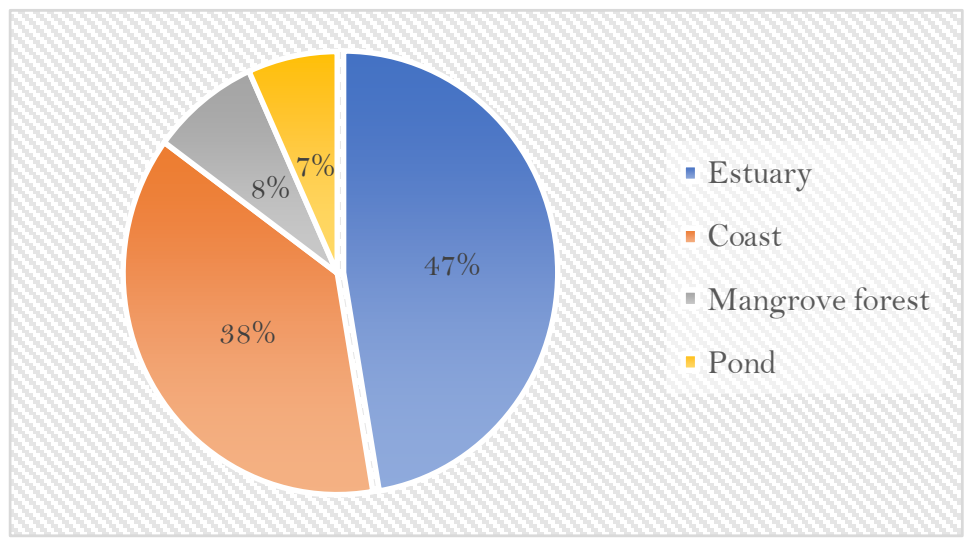

Figure 3. Proportion of Calidris alba on the South Coast of Puger, Getem.

The four survey locations were river estuaries, mangrove forests, ponds, and along the southern coastline of Puger, Getem (Figure 1). The total population of Sanderling (Calidris alba) at four locations was 445 individuals (Table 1 and Figure 3). The first location was Muara Sungai, with a total of 231 individuals. Then the Coastal Coast tallied a total of 184 individuals. The total number of mangrove forests is 40 individuals, and the last location of the Tambak (fish ponds) area is the calculation of the total number of 33 individuals. Taufiqurrahman et al. (2010) stated that Sanderling (Calidris alba) record with an estimated 1,845 individuals was present on January 2, 2010, at Trisik Beach, precisely on the south-central coast of Java. This location is recognized as a site of international importance because it covers $37 \%$ of Indonesia's estimated population. In another study, Ming Ge et al. (2006) stated that adult shorebirds use different migration routes during fall migration or use the same way but do not stop at river mouths. Instead, some relied on coastal stopovers for food during their first trip south.

The results of data analysis on population density of Sanderling (Calidris alba) in Estuary showed a value of 57.75 (individual/ha). Coastal 46 (individual/ha). Mangrove Forest 8 (individual/ha) and Pond 6.6 (individual/ha). Estuary is the location with the highest number of the other four survey locations. The location of the pond has the smallest amount of Sanderling population density. Another study states that several species' presence 
in exploiting an area's resources cannot be separated from the company of abundant feed, which makes it the main attraction for a species (Hassan-Aboushiba et al., 2011; Quiroga et al., 2013). Research by Hagy and Kaminsky (2012) recommends: Active management of moist-soil wetlands to increase the use of waterbirds. Those conservation planners consider increasing the foraging threshold in the carrying capacity model for moist-soil wetlands. Conduct additional experiments to explain the foraging threshold in moist soil and other wetlands targeted by the Waterfowl Management Plan by the relevant agencies.

\section{CONCLUSION}

The population of Sanderling (Calidris alba) on the southern coast of Puger and Getem, Jember Regency was 445 individuals. The highest population was found in the river mouths, while the ponds are the minor location. Analysis of bird density data shows that Estuary of the River is the location with the highest number of individuals from the other four survey locations.

\section{ACKNOWLEDGEMENT}

We want to thank fellow bird observers throughout Indonesia for their enthusiasm and support in data collection. We are grateful to the Ministry of Environment and Forestry, the National Partnership for the Conservation of Migratory Birds and Their Habitats, and Wetlands International Indonesia to implement the Indonesia Asian Waterbird Census 2020. We are also grateful to the people of Puger Getem for their assistance and hospitality. Finally, we would like to thank the lecturers, members of the Biology Education Student Ornithology Study Group, FKIP, University of Jember.

\section{REFERENCES}

Alikodra H.S. (1990). Pengelolaan satwa liar jilid I. Departemen Pendidikan dan Kebudayaan. Direktorat Jendral Pendidikan Tinggi Pusat Antar Universitas Ilmu Hayat IPB. Bogor.

Bhushan, B. (1993). A Field Guide to The Waterbird of Asia. Wild Bird Society of Japan in Collaboration with Asian Wetland Bereau with The Assistance Of A Grant From Tokai Foundation. Kodansha International

Borgmann, K. L. (2011). A Review of Human Disturbance Impacts on Waterbirds Kathi L. Borgmann *
Audubon California, 376 Greenwood Beach Rd., Tiburon, California 94920. Waterbirds, 1-23.

Clark, M. R., \& Koslow, A. L. (2008). Impacts of Fisheries on Seamounts. Seamounts: Ecology, Fisheries \& Conservation, $\quad 67, \quad 413-441$. https://doi.org/10.1002/9780470691953.ch19

Crossland, A. C., A. S. Sitorus \& H. A. Chandra. (2010). Discovery of an Important Site for Sanderling Calidris alba on the South Coast of Java. Stilt, The Journal for the East Asian-Australasian Flyway. 1(2): 3-4.

Borgmann, K. L. (2011). A Review of Human Disturbance Impacts on Waterbirds Kathi L. Borgmann * Audubon California, 376 Greenwood Beach Rd., Tiburon, California 94920. Waterbirds, 1-23.

Clark, M. R., \& Koslow, A. L. (2008). Impacts of Fisheries on Seamounts. Seamounts: Ecology, Fisheries \& Conservation. 67, 413-441. https://doi.org/10.1002/9780470691953.ch 19

Crossland, A. C., A. S. Sitorus \& H. A. Chandra. (2010). Discovery of an Important Site for Sanderling Calidris alba on the South Coast of Java. Stilt, The Journal for the East Asian-Australasian Flyway: 3-4.

Crossland, A. C., Sitorus, A. W \& Sitorus, A. S. (2014). Land Use Change ImpactsShorebird Habitat at an Important Site for Javan Plover Charadrius Javanicus and Sanderling Calidris Alba in Java, Indonesia. Stilt: The Journal for the East Asian-Australasian Flyway $66,30-36$.

Hagy, H.M. \& Kaminsky, R. M. (2012). Winter waterbird and food dynamics in autumn-managed moist-soil wetlands in the Mississippi Alluvial Valley. Wildlife Society. 36 (3), 512-523.

Hassan-Aboushiba AB, Ramli R, Sofian-Azirun M. (2011). Species composition and feeding guilds of birds utilizing palm oil mill effluent (pome) area in Carey Island, Malaysia. 2nd International Conference on Environmental Scienceand Technology. Singapura (SG): IPCBEE. 6, 28-31.

Howes, J., Bakewell, D., \& Noor, Y. R. (2003). Panduan Studi Burung Pantai. Bogor : Wetland International.

Kirby, J. S., Stattersfield, A. J., Butchart, S. H. M., Evans, M. I., Grimmett, R. F. A., Jones, V. R., O'sullivan, J., Tucker, G. M., \& Newton, I. (2008). Key conservation issues for migratory land- and waterbird species on the world's major flyways. Bird Conservation International, $\quad 18, \quad$ S49-S73. https://doi.org/10.1017/S0959270908000439

Klein, M. L., Humphrey, S. R., \& Percival, H. F. (1995). Effects of Ecotourism on Distribution of Waterbirds in a Wildlife Refuge. Conservation Biology, 9(6), 14541465.https://doi.org/https://doi.org/10.1046/j.1523 -1739.1995.0906 1454.x

MacKinnon, J., Phillips, K., \& Ballen, BV. (2010). Burung 
Burung Di Sumatera, Jawa, Bali dan Kalimantan Termasuk Sabah dan Brunei Darussalam). Puslitbang Biologi- LIPI \& Birdlife Internasional-Indonesia Programme: 146.

Ming Ge, et. al. (2006). Use of wetlands at the mouth of the Yangtze River by shorebirds during spring and fall migration. 77(4), 347-356

Purify, A. et al. (2019). Water bird habitat suitability analysis in an urban coastal wetland (case study: Lantebung mangrove ecotourism area). IOP Conf. Series: Earth and Environmental Science, 370: 012042.

Quiroga M, Leon E, Beltzer A, Olguin P. 2013. Diet of Black-crowned Night-herons (Nycticorax nycticorax) in wetlands of the Parana River's Alluvia Valley. Ekoloji. 22(88), 43-50.

Riegen. (2005). Crossing the Ultimate Ecological Barrier: Evidence for an $11000-\mathrm{km}-$ Long Nonstop Flight from Alaska to New Zealand and Eastern Australia. Godwits, The Condor. 107 (1): $1-20$.

Rodgers Jr., J. A., \& Schwikert, S. T. (2002). Buffer-Zone Distances to Protect Foraging and Loafing Waterbirds from Disturbance by Personal Watercraft and Outboard-Powered Boats. Conservation Biology.
16(1), 216-224. https://doi.org/https://doi.org/10.1046/j.15231739.2002.00316.x

Sibuea, T.Th, Y. Rusila-Noor, M.J. Silvius, dan A. Susmianto. (1995). Burung Bangau, Pelatuk Besi dan Paruh Sendok di Indonesia. Panduan untuk Jaringan Kerja. Jakarta: PHPA \& Wetlands InternationalIndonesia Programme.

Studds, C., Kendall, B., Murray, N. (2017). Rapid population decline in migratory shorebirds relying on Yellow Sea tidal mudflats as stopover sites. Nat Commun. 8: 14895 .

Taufiqurrahman, I., Tampubolon, A. M., Subekti, H., \& Ulya, H. Z. (2010). Pantai Trisik, Yogyakarta: another internationally important site for Sanderling Calidris alba in Indonesia. Stilt. 58, 57.

Tian B, Zhou Y, Zhang L, Yuan L. (2008). Analyzing the habitat suitability for migratory birds at the chongming Dongtan Nature Reserve in Shanghai, China. Estuarine, Coastal and Shelf Science. 80, 296-302.

Yong, D.l., (2018). Challenges and opportunities for transboundary conservation of migratory birds in the East Asian-Australasian flyway. Conservation Biology. 32 (3), 740-743. 